\begin{tabular}{|c|c|c|c|c|c|c|}
\hline \multirow{4}{*}{ Impact Factor: } & ISRA (India) & $=3.117$ & SIS (USA) & $=0.912$ & ICV (Poland) & $=6.630$ \\
\hline & ISI (Dubai, UAE & $=0.829$ & РИНЦ (Russia) & $=0.156$ & PIF (India) & $=1.940$ \\
\hline & GIF (Australia) & $=0.564$ & ESJI (KZ) & $=8.716$ & IBI (India) & $=4.260$ \\
\hline & JIF & $=1.500$ & SJIF (Morocco) & $=5.667$ & OAJI (USA) & $=0.350$ \\
\hline
\end{tabular}

\begin{tabular}{|c|c|}
\hline $\begin{array}{l}\text { SOI: } \frac{1.1 / \mathrm{TA}}{} \\
\text { International Sc } \\
\text { Theoretical } \boldsymbol{\&} \mathbf{A}\end{array}$ & $\begin{array}{l}\frac{S}{\text { DOI: }} 10.15863 / \mathrm{TAS} \\
\text { ientific Journal } \\
\text { pplied Science }\end{array}$ \\
\hline p-ISSN: 2308-4944 (print) & e-ISSN: 2409-0085 (online) \\
\hline Year: 2019 Issue: 06 & Volume: 74 \\
\hline Published: 27.06 .2019 & http://T-Science.org \\
\hline
\end{tabular}

SECTION 28. Pharmaceutical Sciences
QR - Issue

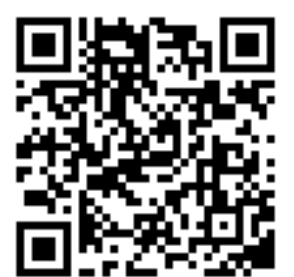

QR - Article

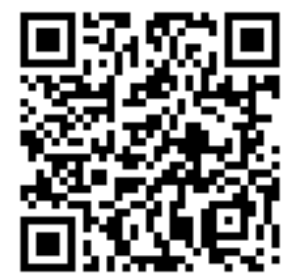

Uliana Ryabinina

Moscow Polytechnic University, Student of Biotechnology faculty,

Moscow, Russian Federation

Natalia Metelitsa

Moscow Polytechnic University, Senior teacher of chair "Foreign Languages"

Moscow, Russian Federation

\title{
CONTINUOUS GLUCOSE MONITORING WITH NEW ADVANCED DEVICES
}

Abstract: The author of the article attempts to make people more acquainted with diabetes and ways to control this pathology. The purpose of this article is to spread out information about the new technology for controlling blood sugar rate. Despite there are a lot of methods for tracking blood sugar, the author proves that a new advanced device makes it much more easier to do.

Key words: diabetes, blood, sugar, pathology, device, technology.

Language: English

Citation: Ryabinina, U., \& Metelitsa, N. (2019). Continuous glucose monitoring with new advanced devices. ISJ Theoretical \& Applied Science, 06 (74), 526-528.

Soi: http://s-o-i.org/1.1/TAS-06-74-62 Doi: crossef https://dx.doi.org/10.15863/TAS.2019.06.74.62

\section{Introduction}

Over the last centuries the idea of changing the world and improving our lifestyle has occupied people's minds. New technologies, new approaches, new processes appear and are rapidly implemented in everyday life of ordinary people. One of the major public issue is extending lives through modifying its quality. Prevention of some habits, constant controlling strategies can reduce the risk and complications of diabetes which are urgently required $[1 ; 180]$

Diabetes is a disease which impairs the body's ability to process blood glucose. It happens because the pancreas stops carrying out its function properly. The organ does not secrete enough insulin or does not secret that compound at all. If insulin is absent, your body cannot obtain enough glucose so it stays in bloodstream and level of blood sugar spikes. Glucose is the main source of energy for our body. When cells are lack of this monosaccharide it means they do not have enough energy to carry out their functions. Therefore, over time high blood sugar leads to such problems as heart diseases, strokes, kidney diseases, eye problems, dental diseases, nerve damages, and foot problems.
There are three main types of diabetes. Type 1 diabetes is a condition when the body does not make insulin. The person's immune attacks and destroys cells of the pancreas which produce this hormone called islets. Therefore, people who have type 1 diabetes are called insulin-dependent. They need to get artificial insulin in order to stay alive. One of their options is to constantly use the insulin pump. This is a machine that transfers small doses of insulin throughout the day. Besides insulin pump, there are other ways of delivering insulin. For instance, insulin shot by syringe, needle or special pen, inhaler method. Type 2 diabetes is also known as insulin resistance. The pancreas is not capable of making enough of insulin to transport glucose or the cells that are dedicated to obtaining insulin, become less permeable to the hormone so we need more of it. Such a condition could arise in every age. Type 2 diabetes is strongly linked to obesity. However, the disease could occur also because of genetic mutations. The third type of diabetes is gestational diabetes. It occurs while pregnancy because a woman's body becomes less sensitive to insulin. Physicians prescribe different types of insulin to each patient according to a person's overall lifestyle. There are rapid-acting, regular, intermediate-acting and long-acting types of insulin 


\begin{tabular}{|c|c|c|c|c|c|c|}
\hline \multirow{4}{*}{ Impact Factor: } & ISRA (India) & $=3.117$ & SIS (USA) & $=0.912$ & ICV (Poland) & $=6.630$ \\
\hline & ISI (Dubai, UAI & $=0.829$ & РИНЦ (Russia & $=0.156$ & PIF (India) & $=1.940$ \\
\hline & GIF (Australia) & $=0.564$ & ESJI (KZ) & $=8.716$ & IBI (India) & $=4.260$ \\
\hline & JIF & $=1.500$ & SJIF (Morocce & $=5.667$ & OAJI (USA) & $=0.350$ \\
\hline
\end{tabular}

[2]. Also, sometimes doctors prescribe premixed insulin. This is a mix of two types of insulin.

A well-known fact is that diabetes has no cure. Therefore, people exposed to this sickness need always follow a special diet, be active and constantly track their blood sugar level in order to comprehend how much insulin to insert [3]. There are some ways of tracking this parameter. The most common for monitoring is a blood glucose meter. This is a small portable device with a lancet for pricking the side of your fingertip in order to get a drop of blood for analysis. Another way of tracking your blood sugar is CGM or continuous glucose monitoring. That device constantly supplies you with information about the glucose level in the bloodstream. This is very comfortable because you can make more precise decisions about your food, medicines and physical activity [4].

First CGM was approved by the FDA in 1999 [5]. It worked through a tiny sensor, which was implanted under your skin of arm or belly. The sensor detected glucose in the liquid between cells. After the detection, this mechanism sent information to the insulin pump or the pocket-sized device. CGM is mostly applicable to people with type 1 diabetes, however, there are cases when CGM is vital for people with type 2 diabetes as well. For example, if you need to control the health of your child, it is obviously useful. Furthermore, you might get a recommendation to use CGM, if you have got hypoglycemia unawareness, frequent leaps of blood sugar or if you are on intensive insulin therapy.

Overall, CGM devices help people to manage their blood glucose better, hence to avoid low blood sugar emergencies. However, you could not rely solely on CGM results. It means that in order to change your insulin dose you needed to prick your finger with finger-stick glucose test to check your sugar rate. This type of checking your blood sugar was mandatory while using the CGM device. What's more, you also needed to replace the sensor every 7 or 14 days respectively to the model. The two disadvantages mentioned above make the device less comfortable. But as science is moving forward we have more and more advanced and convenient technologies.

For example, The FDA has approved new Eversense CGM device made by Senseonics for patients in the USA [6]. The system consists of a tiny pill-sized sensor, on-body transmitter and a smartphone app for analyzing data. The main advantage of the Eversense CGM device is that the sensor is implanted in the upper arm for 90 days. Therefore, you don't have frequently extraction of the sensor required by other CGMs (e.g., Abbott's FreeStyle Libre, Dexcom G5/G6, Medtronic's Guardian Sensor 3) [7]. The implantation of the sensor occurs in a healthcare provider's office. It takes around 5 minutes to make a professional insertion procedure. What' more, the sensor isn't seen through the skin surface. Eversense CGM transmitter is located above the sensor and can be easily removed at any time without disturbing the sensor. This transmitter vibrates while there is high or low sugar rate even when the phone is out of range. It is really useful for those who have impaired vision or hearing ability. But there is one disadvantage. The patient cannot change his dose of insulin according to results Eversense CGM system shows.

However, there is another device called Dexcom G6 which does not require finger-stick calibration. That is why you can alter insulin dose on your own. Dexcom G6 system is comprised of the same pieces but the sensor is a bit different. The insertion of it is carried out by the patient himself. Dexcom G6 system has been upgraded so now it has one-bottom applicator which makes insertion of the sensor less painful.

As we see each patient can find what is more convenient for him. Both systems mentioned above are resistant to acetaminophen, the chemical that is used for soothing different aches and inflammations, so results are accurate even when taking this pill. Particularly Eversense CGM device was tested on interfering with different substances [8]. The carried out research has proved that the Eversense sensor does not interfere with acetaminophen and ascorbic acid. It's a huge CGM breakthrough because people frequently reported about that interference. However, electrochemical-based transcutaneous CGM system reacts with tetracycline and mannitol. Everesens and Dexcom G6 are provided with handy apps compatible with Apple and Android. It means that you always have got easy access to your health data. Sensors send data every 5 minutes to smartphones. Moreover, patients can share their health statistics with their physicians at once. There was a large study carried out in the USA which was assessing the accuracy of CGM system Dexcom G6 [9]. The researched showed that G6 results were almost the same with laboratory ones so the study has approved accuracy of this device. That is why the FDA let people change their dose of insulin according to G6. These systems are truly wellmade and thoroughly considered. American Diabetes Association checked Eversense sensor on toxicity. Scientists were suspicious about the dose of dexamethasone acetate included in the silicon collar of the sensor. Although DEX is a compound preventing inflammatory processes and improving outcomes, some studies have shown a potential user risk to exposure to that chemical. There were clinical trials. During them, DEX level in plasma was measured each day throughout the whole life cycle of the Eversense system - 90 days. The results showed that the dosage of DEX didn't outreach the norm [10]. The rate of dexamethasone acetate was always below the necessary concentration for an organism's 


\begin{tabular}{|c|c|c|c|c|c|c|}
\hline \multirow{4}{*}{ Impact Factor: } & ISRA (India) & $=3.117$ & SIS (USA) & $=0.912$ & ICV (Poland) & $=6.630$ \\
\hline & ISI (Dubai, UAI & $=0.829$ & РИНЦ (Russia & $=0.156$ & PIF (India) & $=1.940$ \\
\hline & GIF (Australia) & $=0.564$ & ESJI (KZ) & $=8.716$ & IBI (India) & $=4.260$ \\
\hline & JIF & $=1.500$ & SJIF (Morocce & $=5.667$ & OAJI (USA) & $=0.350$ \\
\hline
\end{tabular}

response. This fact demonstrates the safety of Eversense system.

The devices mentioned above really give hope to people exposed to diabetes. And there are lots of these people. A scale of the disease is overwhelming. Diabetes caused death to 1,5 million people in 2015 but if we add death related to high blood sugar, the number will increase up to 3,7 million. There were 1,6 million deaths in 2016. Now it is slowly decreasing because of improvements in medical service. However, a number of people having diabetes is still growing. For instance, 1,5 million people are diagnosed with diabetes in America each year.

As we still do not have a cure to diabetes we reckon that using ubiquitously such sensors as Everesens system or Dexcom G6 is the best option. We are sure that those devices are going to prevent plenty of deaths connected to high blood sugar because implantable systems are equipped with alarm signal mechanisms. In the near future, these sensors might become more advanced. For instance, people may be able to keep the sensor in their body for the whole year and there might not need to check the glucose rate twice a day by pricking the finger with a glucometer lancet. The sensor might be so sensitive and accurate that information which it gets may be very close to laboratory results. What's more, when the mankind attains the point of such technologies, we guess, the industry and the scientific community working on that issue will unite in order to spread these sensors throughout the society by making them cheaper. We predict that each medical office will provide its patients exposed to diabetes with CGM sensors. It will be easier to create an effective treatment plan because of new gathered information. The database collected by the sensors will be tremendous so it will be possible to notice some new disease patterns and invent smart algorithms for treating diabetes. However, we cannot just sit and wait for changes in medicine service. Therefore, for all who needs support, desire changes or who are seeking more information about your disease, we advise you to look through the website of the International Diabetes Federation.[11, 12] They have got plenty of available easy-written information about diabetes, education programs, diabetes voice center, support group and much more.

\section{References:}

1. Shrestha, P., \& Ghimire, L. (2012). A Review about the Effect of Life style Modification on Diabetes and Quality of Life. Glob J Health Sci., Nov; 4(6): 185-190.

2. Kropff, J., \& DeVries J. H. (2016, Feb.). Diabetes Technology \& Therapeutics. ahead of print Retrieved April 04, 2019, from http://doi.org/10.1089/dia.2015.0345

3. (2017). Centers for Disease Control and Prevention. National diabetes statistics report, 2017. Centers for Disease Control and Prevention. Retrieved April 28, 2019, from www.cdc.gov/diabetes/pdfs/data/statistics/natio nal-diabetes-statistics-report.pdf

4. (2015). Diabetes Prevention Program Research Group. Long-term effects of lifestyle intervention or metformin on diabetes development and microvascular complications over 15-year follow-up: the Diabetes Prevention Program Outcomes Study. The Lancet Diabetes \& Endocrinology, 3 (11), 866-875.

5. (2016). American Diabetes Association. Classification and diagnosis of diabetes. Diabetes Care, 39(Suppl. 1), pp.13-22.
6. (n.d.). official website of the Eversense system. Retrieved April 30, 2019, from https://www.eversensediabetes.com/

7. (n.d.). official website of the Dexcom G6. Retrieved April 30, 2019, from https://www.dexcom.com/g6-cgm-system

8. Lorenz, C., Sandoval, W., \& Mortellaro, M. (2018, May). Diabetes Technology \& Therapeutics. ahead of print. http://doi.org/10.1089/dia.2018.0028

9. Shah, V. N., Laffel, L. M., Wadwa, R. P., \& Garg, S. K. (2018, June). Diabetes Technology \& Therapeutics. ahead of print. http://doi.org/10.1089/dia.2018.0143

10. (n.d.). Integration of Novel Emerging Technologies for the Management of Type-2 Diabetes.

11. (n.d.). International Diabetes Federation. Retrieved 2019, from https://idf.org/52-aboutdiabetes.html

12. (n.d.). National Institute of Diabetes and Digestive and Kidney disease. Retrieved 2019, from https://www.niddk.nih.gov/ 